\title{
Stakeholder analysis in the biomass energy development based on the experts' opinions: the example of Triglav National Park in Slovenia
}

\author{
Gianluca Grilli ${ }^{1,2} \bowtie$, Giulia Garegnani ${ }^{2}$, Aleš Poljanec $^{3,4}$, Andrej Ficko $^{4}$, Daniele Vettorato ${ }^{2}$, \\ Isabella De $\mathrm{Meo}^{5}$, Alessandro Paletto ${ }^{6}$ \\ ${ }^{1}$ University of Trento, Department of Civil, Environmental and Mechanical Engineering, via Mesiano 77, 38123 Trento, \\ Italy, phone: +390471 055 668, email: Gianluca.Grilli@eurac.edu \\ ${ }^{2}$ EURAC Research, Institute for Renewable Energy, Viale Druso Drususallee 1, Bozen, Italy \\ ${ }^{3}$ Slovenia Forest Service, Večna pot 2, 1000 Ljubljana, Slovenia \\ ${ }^{4}$ University of Ljubljana, Biotechnical Faculty, Department for Forestry and Renewable Forest Resources, \\ Jamnikarjeva 101, 1000 Ljubljana, Slovenia \\ ${ }^{5}$ Council for Agricultural Research and Economics, Agrobiology and Pedology Centre - CREA-ABP, Firenze, Italy \\ ${ }^{6}$ Council for Agricultural Research and Economics, Forest Monitoring and Planning Research Unit - CREA-MPF, \\ Trento, Italy
}

\section{Abstract}

The paper presents a method for identifying and classifying local stakeholders involved in renewable energy development. The method is based on the expert assessment and comprises three main steps: (1) identification of the independent experts considering their expertise and knowledge of the local context; (2) identification of the local stakeholders based on expert assessment; and (3) analytical categorisation of stakeholders taking into account the professional relationship network. Using forest biomass (bioenergy) production as example, the stakeholder analysis is illustrated on the case study of Triglav National Park, which is characterised by a high potential of woody biomass production and a large number of stakeholders involved in land use and management. The first stage of stakeholder analysis identifies the key stakeholders to be involved in bioenergy development, through a survey with local experts. The results highlight eight key stakeholders and several primary and secondary stakeholders that should be involved to ensure socially acceptable decision-making about the renewable energy development in the Triglav National Park.

\section{KeY WORDS}

renewable energy, biomass supply, stakeholder analysis, social network analysis, land management and development 


\section{INTRODUCTION}

The policy decisions concerning land management increasingly require participatory planning processes, in which local actors are actively involved in the decisionmaking process (Bourgoin 2012). A participatory planning process, where all the interests at stake are considered, promotes the social acceptability of the decisions, reduces conflicts between users, facilitates cooperation between local actors and reduces hostility (Kangas et al. 2006; Miron and Preda 2009). Inclusion of social priorities in the decision-making process at local level is expected to facilitate community capacity building and the empowerment of local communities (Craig 2007).

Within the sustainable land management policies, renewable energies (RE) are contributing to the three pillars of sustainable development (social, economic and environmental) (Pirlogea and Cicea 2012). In particular, by the development of RE, the targets set in the European Union's climate and energy package (Directive 2009/28/EC) may be achieved: the raise of the share of RE consumption produced from renewable resources to $20 \%$ in 2020 and the reduction of the greenhouse gas (GHG) emissions by 20\% compared to 1990 levels.

In RE development programs, the incorporation of the preferences and needs of the stakeholders in the decision-making process is essential to ensure the successful formulation and implementation of energy policy (Gregory and Wellman 2001). Understanding stakeholders' attitudes towards RE and their local development should steer the bioenergy policy (Dwivedi and Alavalapati 2009; Kraxner et al. 2009) and guide decision makers in programmes and policies implementation. Despite the general public support for the RE development, the opposition to RE systems (e.g. wind, solar or hydropower plants) may sometimes appear at the local level (Higgs et al. 2008). To avoid conflicts, the development of RE systems must take into account an ample range of attitudes and objectives by involving local actors in the decision-making process.

Before the participatory decision-making process can start, it is essential to conduct a comprehensive stakeholder analysis. Stakeholders are social actors who may benefit or suffer from the outcomes of a project or a plan (Grimble and Wellard 1997) and they can be of any size, aggregation or level in society (Grimble and Chan 1995; Nichiforel 2011). The stakeholder analy- sis is a technique that is used to identify all groups of people, organised or unorganised, who share a stake in a particular issue, their interests, the conflicts of interests between different stakeholders and the possible 'coalitions' (Mitchell et al. 1997). On the other hand, the stakeholder analysis is used to identify and analyse the potential 'supporters' and 'opponents' to the project (Čiegis and Gineitiene 2008).

The primary objective of the stakeholder analysis is to define the level of participation - that may vary from passive consultation to active engagement - and the manner in which the different stakeholders should be involved in the decision-making process (Miron and Preda 2009). To achieve this, stakeholder analysis can be realised through two steps (Reed et al. 2009): the first step consists of the identification of local stakeholders, whilst the second step concerns the analytical categorisation or classification of the stakeholders in categories (e.g. key stakeholders, primary stakeholders and secondary stakeholders). In the first step, stakeholders affecting and affected by policies, decisions and actions of the system should be recognised, whilst the second step is finalised to determine groups of stakeholders with different levels of interest and influence over the issue.

Starting from these general considerations, the aim of the paper is to build an objective and replicable method useful for identifying and classifying local stakeholders. Stakeholders may be totally overlooked when using the classical two-step stakeholder analysis. The innovative aspect of the method is that the stakeholder analysis is based on expert assessment, using the social network analysis in order to categorise the stakeholders. Consequently, the stakeholder analysis proposed by Reed et al. (2009) has been modified and adapted.

The method is illustrated in the bioenergy sector, because the use of woody biomass from forests is expected to increase by $8 \%$ of the expected total increase in RE use in the EU countries between 2006 and 2020 (Beurskens et al. 2011; Blennow et al. 2014). In addition, much of the wood in the EU comes from small-scale private forest owners being an important part of local communities.

The method was tested in the study area of Triglav National Park (TNP) in Slovenia. The area - involved in the Alpine Space recharge.green project (SvadlenakGomez et al. 2014) - is characterised by a high po- 
tential of woody biomass extraction from forests and a large number of actors and interests involved in land management.

\section{MATERIALS AND MEtHOdS}

\section{Study area}

TNP is the only national park and the largest protected area in Slovenia. It was named after Triglav, the highest Slovenian mountain (2,864 m). TNP ( $46^{\circ} 22^{\prime} 00^{\prime \prime} \mathrm{N}$, $13^{\circ} 49^{\prime} 00^{\prime \prime}$ E) extends in the north-western part of Slovenia. Its territory occupies almost the entire area of the Slovenian part of the Eastern Julian Alps. It covers an area of almost $840 \mathrm{~km}^{2}$, which is nearly $4 \%$ of the Slovenian surface. TNP has been created in 1924 as the first protected area, the Alpine Conservation Park.

The landscape in TNP is characterised by glaciershaped valleys, mountain plateaus and steep mountain ridges above the tree line. It is a typical mixture between unspoiled nature areas and cultural landscape. Forest covers two-thirds of the park's territory. The typical forest types in the park are (SFS 2012): Montane beech forests on carbonate parent rock (27,981 ha), Dwarf pine forests (11,350 ha), Silver fir - beech forests $(4,925 \mathrm{ha})$ and Silver fir and Norway spruce forests (4,191 ha).

The climate of the area is continental, with cold winters and warm summers with frequent hot days. The average temperature in the warmest month range from $20^{\circ} \mathrm{C}$ in the valleys and $5.6^{\circ} \mathrm{C}$ in the mountains, and in the coldest month, the temperature ranges is between $0.7^{\circ} \mathrm{C}$ and $-8.8^{\circ} \mathrm{C}$. The average annual precipitation is about 1,500 $\mathrm{mm}$ (Pristov et al. 1998).

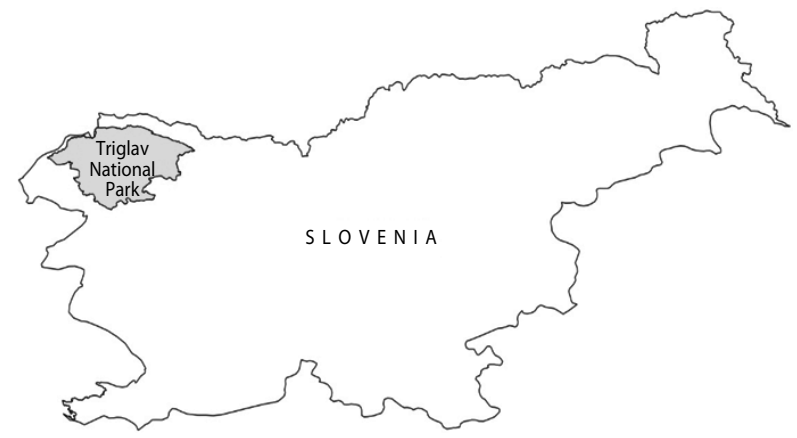

Figure 1. Location of the case study (Triglav National Park) in Slovenia
The park includes parts of 6 municipalities and 25 settlements with a population of 2,444 people (1,018 households, 0.029 inhabitant/ha). TNP attracts around two million of visitors per year by high degree of forest multifunctionality with special regards to recreation, biodiversity and protected nature (Lisec and Drobne 2009; Stubelj Ars 2013).

\section{Method}

The method of research is based on a survey developed in three steps: (1) identification of the experts through brainstorming amongst the partners of recharge.green project; (2) identification of local stakeholders through experts' opinions and information; (3) analytical categorisation (classification) of stakeholders into professional relationship network.

\section{Identification of the experts}

In the first step, in a brainstorming session, the researchers of the recharge.green project together with local partners identified the experts. The researchers and local partners involved in the brainstorming session were chosen based on three criteria: (1) multidisciplinary expertise in economic and social sciences, engineering and life sciences; (2) no direct stake in the outcome of the project; (3) direct or indirect involvement in the recharge.green project's team. Indeed, the major selection criterion used to identify the experts was their professional experience in one of the following sectors: forest management and planning, environment conservation, rural development and $\mathrm{RE}$ development. Besides, the experts were chosen on the basis of their expertise and knowledge of the local context. At the end of the brainstorming session, 13 experts were identified; 11 of them were strictly related to the forest bioenergy sector. The identified experts belong to the following institutions and organisations: Slovenia Forest Service, Association of forest owners, Institute of the Republic of Slovenia for Nature Conservation, Forest company GG Bled, DOPPS - Birdlife Slovenia, Agricultural/Forest Cooperative, Bled tourism organisation and University of Ljubljana. The basic idea of the selection of the experts was that the information and opinions they provide could lead to a more balanced identification of main stakeholders and their connections in the field of RE. 
Identification of local stakeholders through experts' opinions and information

The experts were interviewed with a semi-structured questionnaire consisting of 19 closed-ended questions and 1 open-ended question subdivided into 6 thematic sections: (a) Personal information; (b) Opinions concerning RE development; (c) Impacts of the RE technologies on ecosystem services; (d) Impacts of RE technologies on the socio-economic features; (e) Perceived risks and benefits regarding the development of RE; (f) Stakeholder analysis. In this paper, the results of the thematic section "Stakeholder analysis" are presented.

Table 1. Attributes used to identify local stakeholders

\begin{tabular}{|c|l|}
\hline Attribute & \multicolumn{1}{|c|}{ Description } \\
\hline Power & $\begin{array}{l}\text { Power can be considered as the ability of } \\
\text { an individual to exert influence on another } \\
\text { person in a relationship, in order to obtain the } \\
\text { expected outcomes (Simpson et al. 2014). In } \\
\text { a more detailed way, power can be defined as } \\
\text { the potential to influence and is a basic force } \\
\text { in social relationships (Keltner et al. 2003); } \\
\text { influence can be considered the exercise of } \\
\text { power (Etzioni 1964; Turner 2005) }\end{array}$ \\
\hline Legitimacy & $\begin{array}{l}\text { Legitimacy includes contractual relationship } \\
\text { based on legal, moral or ownership rights or } \\
\text { relationship based on the exchange of one or } \\
\text { more critical resources (Evan and Freeman } \\
\text { 1988). Mitchell et al. (1997) considered } \\
\text { legitimacy and power as two important } \\
\text { independent variables, but from the practical } \\
\text { point of view - concerning the involvement } \\
\text { of stakeholders in decision-making process } \\
\text { - in many cases regarded as legitimate } \\
\text { stakeholders, which ones who have power } \\
\text { (Driscoll and Starik 2004) }\end{array}$ \\
\hline Proximity & $\begin{array}{l}\text { Urgency can be defined as the stakeholder's } \\
\text { claim for immediate attention based on } \\
\text { the ideas of time sensitivity or importance } \\
\text { of the issue such as risks to human health } \\
\text { associated with critical and chronic long-term } \\
\text { environmental problems }\end{array}$ \\
\hline $\begin{array}{l}\text { Iroximity indicates both the spatial proximity } \\
\text { of stakeholders to the resource and the } \\
\text { stakeholders' dependence for their livelihoods } \\
\text { from resource. Besides, spatial nearness is an } \\
\text { important factor in the stakeholder recognition } \\
\text { and interaction (Driscoll and Starik 2004) }\end{array}$ \\
\hline
\end{tabular}

The identification and categorisation of the local stakeholders was done by means of two questions. In the first question, respondents (i.e. experts) were asked to indicate local stakeholders that should be involved in the participatory decision-making process. Each stakeholder was then identified by four key attributes (Michell et al. 1997; Driscoll and Starik 2004; Proscovia Mutekanga et al. 2013): power, legitimacy, urgency and proximity (Table 1). The final list of stakeholders was established based on the individual assessment of the four attributes.

In the second question, experts identified the stakeholders with whom they maintain professional relationship in the field of RE. The relationship was defined as (a) the coordination for action development, (b) the joint realisation of technical initiatives and scientific projects on the territory and (c) the provision of grants and other economic aspects.

By a follow-up question, the strength of the relationships between the stakeholders was measured. A threepoint scale $(0=$ occasional, $1=$ regular, $2=$ permanent $)$ was used. The strength of the ties was assessed through the experts responses, distinguishing between strong and weak ties (Granovetter 1973). Strong ties comprehend all those type of relationships in which either the persons were involved in an emotional manner or frequent and intense communication amongst persons occurred. Weak ties include relationships established by different persons amongst which communication is sporadic and emotional intensity is generally low or, occasionally, moderate (Prell et al. 2009).

Analytical categorisation of stakeholders identified by the experts into the professional relationships network

In the third step, professional relationships were analysed with the social network analysis (SNA), resulting in the classification of stakeholders. The SNA is a social science technique developed in the 1960s and 1970s for defining and analysing the relationships that individuals or organisations have with each other (Wasserman and Faust 1994). It is one of the techniques used for the investigation of the relationships that exist between stakeholders (Reed et al. 2009). SNA consists of a set of analytical techniques to transform individual responses into maps of network structure, allowing researchers to quantify the structure of relationships between the individuals (Neal 2009). SNA is considered an important support tool in participatory planning processes (Prell et al. 2009), particularly when decision makers are fac- 
ing multiple use preferences and diverse objectives, as is the case of natural resources management (Bodin and Crona 2009; Hahn et al. 2006). The social network analysis is crucial to addressing a diverse set of societal important issues and can facilitate the conflicts resolution amongst users, increases opportunities for peer-to-peer learning and collective actions (Ernstson et al. 2008) and reveals the diffusion of information (Paletto et al. 2012; Korhonen et al. 2013).

The social network can be analysed by the features of the whole network such as density, centralities (degree centrality, betweenness centrality, closeness centrality and eigenvector centrality), cluster coefficient and cliques, or focuses on a specific feature of the network. Moreover, social interactions in the network can be approached either from the perspective of an actor in an environment (egocentric approach) or from the perspective of the environment itself (sociocentric approach) (Freeman 1979). Egocentric design obtains information only about the portion of the network in the immediate locality of a given social actor (Marsden 2002). This design does not require a priori enumeration of a population (total number of stakeholders) and is often used to measure social networks in surveybased studies (Marsden 2002). In this study, we used two ego-network features, that is, ego degree centrality and ego network betweenness to classify the stakeholders of the TNP into three categories (Table 2): key stakeholders, primary stakeholders and secondary stakeholders. Particularly, the data about the current professional relationships between experts and stakeholders and the strength of relationships are used to calculate ego degree centrality and ego betweenness centrality.

Table 2. Description of the categories of stakeholders

\begin{tabular}{|l|l|}
\hline $\begin{array}{c}\text { Category } \\
\text { of stakeholders }\end{array}$ & \multicolumn{1}{|c|}{ Description } \\
\hline Key stakeholders & $\begin{array}{l}\text { Key stakeholders are those who can } \\
\text { significantly influence or are important to } \\
\text { the success of a project, plan or action }\end{array}$ \\
\hline $\begin{array}{l}\text { Primary } \\
\text { stakeholders }\end{array}$ & $\begin{array}{l}\text { Primary stakeholders are those who are } \\
\text { affected either positively (beneficiaries) } \\
\text { or negatively by the results of a project, } \\
\text { plan or action }\end{array}$ \\
\hline $\begin{array}{l}\text { Secondary } \\
\text { stakeholders }\end{array}$ & $\begin{array}{l}\text { Secondary stakeholders are those who } \\
\text { have marginal effect on the results of } \\
\text { a project, plan or action }\end{array}$ \\
\hline
\end{tabular}

Degree centrality is the key concept in the network analysis; it is closely associated with stakeholders' social status, power and satisfaction with group activities (Mizruchi and Potts 1998). The social status and the power of a stakeholder are two fundamental aspects that must be considered in the participatory decisionmaking process (Paletto et al. 2014a). Considering the participatory planning process, power quantifies the influence that stakeholders have in the decision-making process and their capacity to convince the decision makers to take different actions (Nichiforel 2011). Degree centrality expresses the number of stakeholders with which a certain actor maintains relations, and it can be considered an appropriate indicator of stakeholder's real power (Mizruchi and Potts 1998). From the theoretical point of view, according to Bavelas (1950) and Leavitt (1951), the network centrality is a fundamental concept to account for actors' social status and power with group activities. In the international literature, there are some studies that showed a positive relationship between network centrality and power (Brass 1984; Krackhardt 1990). According to Freeman (1979), degree centrality was defined as the number of alters to whom an actor is directly tied and represents the ability to communicate directly with others (level of communication activity). Considering these theoretical assumptions, the degree centrality can be considered as a indirect measure of the stakeholders' power.

According to Everett and Borgatti $(2005,32)$, 'degree centrality is a local property and the ego degree centrality of ego is the same as the degree of the actor in the whole network there is no issue'. In addition, Marsden (2002) asserted that degree centrality measures based on egocentric and sociocentric data are in principle identical. Consequently, we decided to use the degree centrality of each stakeholder (ego) as an indicator of the personal power. The formula used to calculate the degree centrality $\left(S_{e}\right)$ was the following:

$$
S_{e}=\sum_{k=1}^{N} a\left(p_{i}, p_{k}\right)
$$

As the egocentric network $A_{i}$ for stakeholder $p_{i}$ includes all other stakeholders $p_{k}$ such that $a\left(p_{i}, p_{k}\right)=1$.

Betweenness centrality measures the influence that a stakeholder has over the spread of information 
through the network and, therefore, identifies those stakeholders who have an intermediary role in the decision-making process (Paletto et al. 2012). In other words, betweenness centrality can be regarded 'as a measure of the extent to which a stakeholder has control over information flowing between others' (Newman 2005, 40). According to Marsden (2002), egocentric betweenness often may be a reliable substitute for Freeman's sociocentric betweenness measure. Besides, some authors demonstrated that there is a connection between the betweenness of the actor in the whole network (i.e. sociocentric betweenness) and the betweenness of the actor in the ego network (i.e. egocentric betweenness) (Everett and Borgatti 2005). Ego betweenness centrality was measured by the extent to which a stakeholder lies on paths linking other stakeholders (Freeman 1979; Marsden 2002), and it can be calculated with the following formula:

$$
B_{e}=\sum_{u=1}^{N} \sum_{v=1}^{u=1} p_{u v}(f) / p_{u v}
$$

where:

$B_{e} \quad$ - the ego betweenness centrality,

$u, v$ - the stakeholders in the ego network of stakeholder $f$,

$N \quad$ - the total number of stakeholders in the ego network,

$p_{u v} \quad$ - the total number of network paths linking stakeholder $u$ and stakeholder $v$,

$p_{u v}(f)$ - the number of those paths that include stakeholder $f$.

The ego degree centrality and the ego network betweenness were calculated with UCINET 6.504 (Borgatti et al. 2002). The stakeholders were finally classified by the Individual Index of Importance $\left(I_{i}\right)$ of each stakeholder in the network calculated as the sum of the ego degree centrality and ego network betweenness:

$$
I_{i}=S_{e}+B_{e}
$$

where:

$I_{i}$ - the index of importance of stakeholder $i$,

$S_{e}$ - the ego degree centrality of stakeholder $i$,

$B_{e}$ - the ego network betweenness for stakeholder $i$.

According to Paletto et al. (2015), stakeholders with an $I_{i}$ higher than the third quartile can be con- sidered as key stakeholders, the stakeholders with an $I_{i}$ between the third and first quartile can be classified as primary stakeholders, whilst the other stakeholders can be considered as secondary stakeholders. The thresholds for the stakeholders' classification were chosen on the basis of the distribution of centrality's values, in order to have a balanced number of stakeholders in each category.

\section{Results}

The experts identified 31 stakeholders belonging to the following categories of interests (Table 3): public bodies (51.6\%), local associations/NGOs (19.4\%) and private organisations (29.0\%). The stakeholders most often identified were the public institution of the TNP (nine experts), the Slovenia Forest Service (eight experts) and the Biotechnical Faculty at the University of Ljubljana (seven experts). Most of the experts identified only few stakeholders; a high number of stakeholders (14, corresponding to $45 \%$ of the total) have been mentioned only by one expert. At the end of the first step, the recharge. green project researchers decided to consider all 31 suggested stakeholders in the future stages of the bioenergy development project. Stakeholders were involved at different levels, according to their importance in the network. Key stakeholders were involved for cooperation and consultation; primary stakeholders were consulted, whilst secondary stakeholders were just kept informed about the decisions taken.

The stakeholder with the highest value of both degree and betweenness is the Institute of the Republic of Slovenia for Nature Conservation $\left(S_{e}=13, B_{e}=60.92\right.$, Table 4). Observing the sociogram of stakeholders (Figure 2), we can see that this stakeholder is a 'bridge' between the rest of the network and four stakeholders (i.e. Slovenian Forest Institute, Municipality of Kranjska Gora, Fisheries Research Institute of Slovenia and Ministry of Agriculture and the Environment). High value of degree and betweenness also characterises the Bled-Tourist Association $\left(S_{e}=10, B_{e}=23.00\right)$ and the Forest company GG Bled $\left(S_{e}=6, B_{e}=12.00\right)$. There are some stakeholders with a high value of degree but not of betweenness, such as the Public institution of Triglav National Park $\left(S_{e}=7, B_{e}=2.50\right)$ and the Agrarian community Dovje Mojstrana $\left(S_{e}=5, B_{e}=0.67\right)$. These 
Table 3. List of stakeholders in TNP and number of time they were identified by the experts

\begin{tabular}{|c|c|c|}
\hline Name of stakeholder & Category & $\mathrm{N}^{\circ}$ \\
\hline Public institution of Triglav National Park (TNP) & Public body & 9 \\
\hline Slovenia Forest Service & Public body & 8 \\
\hline University of Ljubljana & Public body & 7 \\
\hline Association of Forest Owners & Private organisation & 5 \\
\hline Municipality of Bohinj & Public body & 5 \\
\hline Institute of the Republic of Slovenia for Nature Conservation & Public body & 4 \\
\hline Agrarian Community Dovje Mojstrana & Private organisation & 4 \\
\hline Company EL-TEC Mulej (Society for Energy and Environmental Solutions) & Private organisation & 4 \\
\hline Agricultural/Forest Cooperative & Association-NGO & 3 \\
\hline Ministry of Agriculture and the Environment & Public body & 3 \\
\hline Forest company GG Bled & Private organisation & 2 \\
\hline DOPPS - Birdlife Slovenia & Association-NGO & 2 \\
\hline Slovenian Environment Agency & Public body & 2 \\
\hline CIPRA Slovenia & Association-NGO & 2 \\
\hline Slovenian Forestry Institute & Public body & 2 \\
\hline Bled-Tourist Association & Private organisation & 1 \\
\hline Alpine Association of Slovenia & Association-NGO & 1 \\
\hline Institute for the protection of Cultural Heritage of Slovenia & Public body & 1 \\
\hline LEAG - Local Energy Agency of Gorenjska & Public body & 1 \\
\hline Fisheries Research Institute of Slovenia & Public body & 1 \\
\hline Municipality of Gorje & Public body & 1 \\
\hline Municipality of Kranjska Gora & Public body & 1 \\
\hline Municipality of Bled & Public body & 1 \\
\hline GOLEA - Goriška Local Energy Agency & Public body & 1 \\
\hline Chamber of Commerce and Industry of Slovenia & Association & 1 \\
\hline RAGOR - Upper Gorenjska Development Agency & Private organisation & 1 \\
\hline Regional Development Agency of Gorenjska & Public body & 1 \\
\hline Association of Hoteliers & Private organisation & 1 \\
\hline Archdiocese of Ljubljana & Church association & 1 \\
\hline Company Lip Bohinj d.o.o. & Private organisation & 1 \\
\hline Machine Club Bled & Private organisation & 1 \\
\hline
\end{tabular}

stakeholders have substantial decision-making power but lower ability to spread information in comparison to other stakeholders (e.g. Institute of the Republic of Slovenia for Nature Conservation and Bled-Tourist Association). The opposite situation is found for the Company EL-TEC Mulej $\left(S_{e}=4, B_{e}=6.00\right)$, which is able to disseminate specific information on renewable energy sources to a group of four stakeholders (Municipality of Bled, Goriška Local Energy Agency, Local Energy
Agency of Gorenjska and Alpine Association of Slovenia) but shows a low power in the decision process.

Furthermore, the index of importance for categories of stakeholders shows that the most important are public bodies that have a total index of importance 120 and an average index of importance of 7.5 per single public body. The private organisations have a total index of importance 73, but an average index of importance per single private organisation is higher than that of public 
bodies (8.2, respectively). NGOs has rather low values excepting Agricultural/Forest Cooperative $\left(\mathrm{I}_{\mathrm{i}}=11.42\right)$.

The classification of stakeholders on the basis of the Index of Importance $\left(I_{i}\right)$ represents eight key stakeholders: Institute of the Republic of Slovenia for Nature Conservation, Bled-Tourist Association, Forest company GG Bled, Slovenia Forest Service, Company ELTEC Mulej, Agricultural/Forest Cooperative, Public institution of Triglav National Park (TNP) and Slovenian
Environment Agency. The other stakeholders can be classified as follows: 6 are recognised as primary stakeholders (Municipality of Bled, Municipality of Bohinj, Association of forest owners, Local Energy Agency of Gorenjska, Agrarian community Dovje Mojstrana and DOPPS - Birdlife Slovenia) and 17 as secondary stakeholders.

Public bodies, private organisations and NGOs are equally represented amongst key stakeholders and

Table 4. Ego degree centrality, ego network betweenness and index of importance of TNP's stakeholders

\begin{tabular}{|c|c|c|c|}
\hline Stakeholders & $S_{e}$ & $B_{e}$ & $I_{i}$ \\
\hline Institute of the Republic of Slovenia for Nature Conservation & 13 & 60.92 & 73.92 \\
\hline Bled-Tourist Association & 10 & 23.00 & 33.00 \\
\hline Forest company GG Bled & 6 & 12.00 & 18.00 \\
\hline Slovenia Forest Service & 8 & 6.50 & 14.50 \\
\hline Company EL-TEC Mulej (Society for Energy and Environmental Solutions) & 4 & 6.00 & 10.00 \\
\hline Municipality of Bled & 2 & 1.00 & 3.00 \\
\hline Agricultural/Forest Cooperative & 7 & 4.42 & 11.42 \\
\hline Public Institution of Triglav National Park (TNP) & 7 & 2.50 & 9.50 \\
\hline Association of Forest Owners & 3 & 2.00 & 5.00 \\
\hline LEAG - Local Energy Agency of Gorenjska & 2 & 1.00 & 3.00 \\
\hline Slovenian Environment Agency & 4 & 3.00 & 7.00 \\
\hline Agrarian Community Dovje Mojstrana & 5 & 0.67 & 5.67 \\
\hline Municipality of Bohinj & 2 & 0.00 & 2.00 \\
\hline DOPPS - Birdlife Slovenia & 4 & 0.00 & 4.00 \\
\hline Company Lip Bohinj d.o.o. & 1 & 0.00 & 1.00 \\
\hline Ministry of Agriculture and the Environment & 1 & 0.00 & 1.00 \\
\hline Machine club Bled & 1 & 0.00 & 1.00 \\
\hline Municipality of Gorje & 1 & 0.00 & 1.00 \\
\hline Municipality of Kranjska Gora & 1 & 0.00 & 1.00 \\
\hline GOLEA - Goriška Local Energy Agency & 1 & 0.00 & 1.00 \\
\hline Alpine Association of Slovenia & 1 & 0.00 & 1.00 \\
\hline Institute for the Protection of Cultural Heritage of Slovenia & 1 & 0.00 & 1.00 \\
\hline CIPRA Slovenia & 1 & 0.00 & 1.00 \\
\hline Fisheries Research Institute of Slovenia & 1 & 0.00 & 1.00 \\
\hline Slovenian Forestry Institute & 1 & 0.00 & 1.00 \\
\hline University of Ljubljana & 0 & 0.00 & 0.00 \\
\hline Archdiocese of Ljubljana & 0 & 0.00 & 0.00 \\
\hline Chamber of Commerce and Industry of Slovenia & 0 & 0.00 & 0.00 \\
\hline RAGOR - Upper Gorenjska Development Agency & 0 & 0.00 & 0.00 \\
\hline Regional Development Agency of Gorenjska & 0 & 0.00 & 0.00 \\
\hline Association of Hoteliers & 0 & 0.00 & 0.00 \\
\hline
\end{tabular}




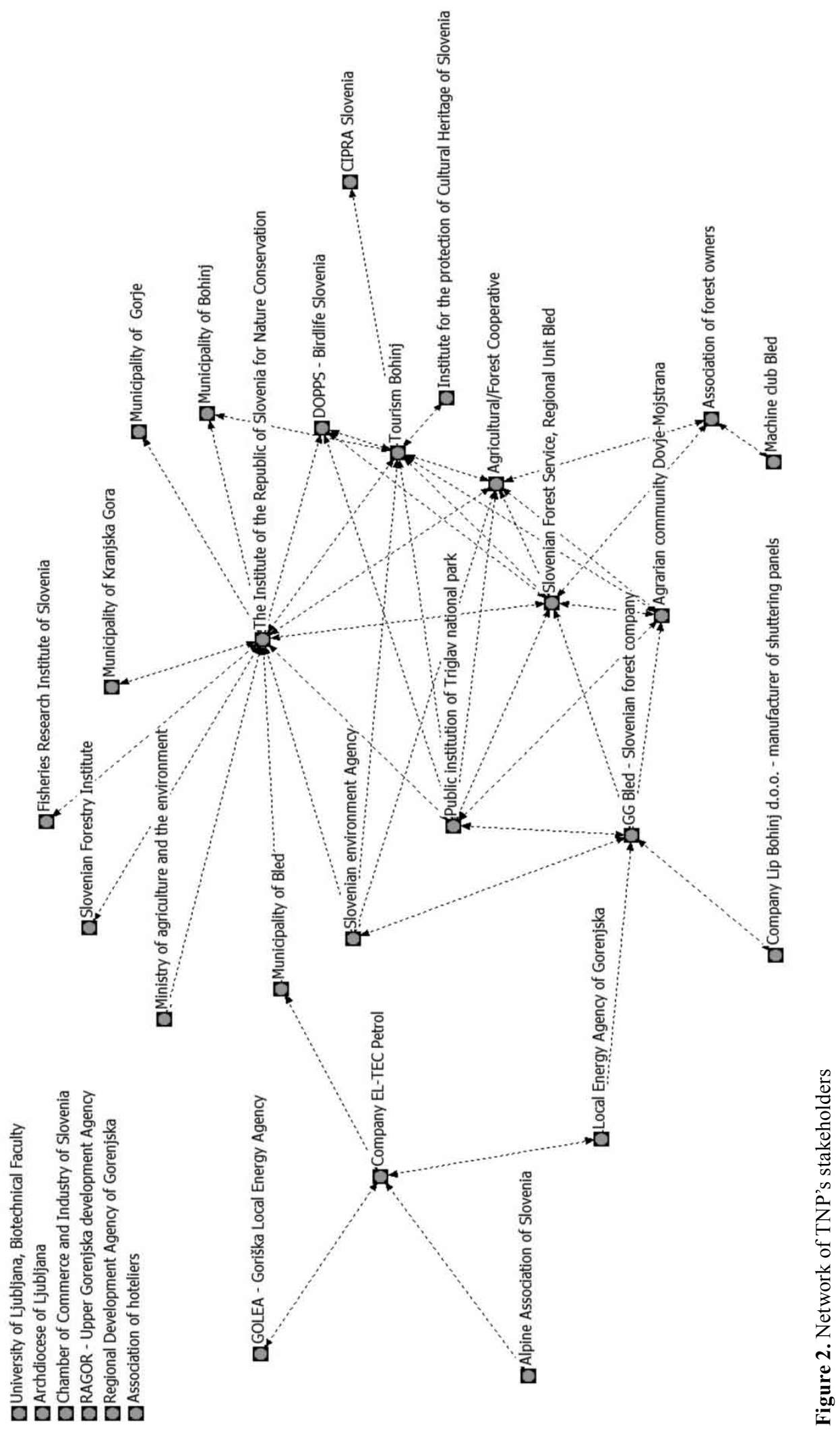


primary stakeholders (i.e. four public bodies, three private organisations and one association amongst key stakeholders and three public bodies, two private organisations and one associations-NGOs amongst primary stakeholders). Conversely, secondary stakeholders consist of mainly public bodies ( 9 of 17 secondary stakeholders).

The network analysis of TNP shows that the key role in the decision process related to renewable energy is not in the hands of one central stakeholder but in those of a group of eight key stakeholders: Institute of the Republic of Slovenia for Nature Conservation, BledTourist Association, Forest company GG Bled, Slovenia Forest Service, Company EL-TEC Mulej, Agricultural/ Forest Cooperative, Public institution of Triglav National Park and Slovenian Environment Agency. Their involvement in the decisions related to RE planning is crucial for the success of the participatory process.

\section{Discussion}

In a participatory process, the choice of the stakeholders to engage is crucial for the success of the decisionmaking process. A high number of stakeholders can make the process slow and inefficient, with the risk of not reaching a shared decision, whilst a low number of stakeholders may not be enough to represent all the interests at stake. Consequently, the development of a method finalised to choose objectively the key stakeholders is important in order not to jeopardise the participatory process (Grimble and Wellard 1997). In literature, there are many methods to identify and classify the stakeholders: Hamersley Chambers and Beckley (2003) classified the stakeholders into three groups, on the basis of the proximity to the resource: local people, interest group that may or may not be local and general public. Indeed, ODA (1995) considered three categories of stakeholders according to their power and legitimacy: key stakeholders are the main actors in the territory in terms of power and legitimacy, primary stakeholders are the beneficiaries of the plan with a less power and legitimacy in comparison with the key stakeholders, secondary stakeholders are the actors marginally involved in the issue. This classification system has been reviewed by Mitchell et al. (1997) considering three categories of stakeholders (definitive stakeholders, ex- pectant stakeholders and latent stakeholders) on the basis of the presence or absence of three variables: power, legitimacy and urgency. Lupo Stanghellini (2010) has further integrated the classification system of Mitchell et al. (1997) with an additional variable: the proximity, which is defined as the state, quality or fact of being near or close in space to the natural resource.

In TNP, the applied method has identified eight key stakeholders: four public administrations, three private organisations and one voluntary association. This distribution amongst categories of stakeholders can be considered a equitable distribution because it is able to consider both public interests and private interests. Indeed, public administrations have the objective of promoting the common goods provided by natural resources, whilst the private organisations have the goal of maximising revenues obtained from the use of natural resources, for example, timber and wood for bioenergy (Rinaldi et al. 2015). The associations-NGOs have in principle the objective of maintaining the resource or enhance the benefits for the whole society (Paletto et al. 2014b).

The results of the present study are comparable with those of another study based on social network analysis, realised in Italy (Paletto et al. 2015). This study, which considered the total network of stakeholders in the forestry sector, identified 5 key stakeholders of the total 25 stakeholders in Matese district (South of Italy) and 8 key stakeholders of the total 44 stakeholders in ArciGrighine (Sardinia island).

Comparing the expert opinion-based identification of stakeholders with the results of social network analysis, some interesting differences could be highlighted: the stakeholders who have been repeatedly mentioned by the experts (Public institution of TNP, Slovenia Forest Service and University of Ljubljana) are not those with the highest relational power. On the opposite, two stakeholders (Bled-Tourist Association and Forest company GG Bled) with high importance was not mentioned by many experts. This confirms that the expertbased identification of stakeholders may provide more realistic picture of the network and reveal some hidden stakeholders with lower importance.

The proposed method of stakeholder analysis has the advantage of being simple and easily applicable, requiring a limited number of data. The basic data can be collected through either a face-to-face interview or 
a self-administered questionnaire. The data analysis using the social network analysis allows the integration of the stakeholder analysis with quantitative information concerning the potential influence of stakeholders during the participatory process. The power and the capacity to control the information flow are two important characteristics of each stakeholder that decision makers will need to consider during the participatory process. The method could be adapted to different decisionmaking needs, assigning a different weight to these two variables in order to emphasise more the power or the capacity to control the information.

The main weakness of the proposed method is related to the exclusion of some stakeholders from the decision-making process. This fact can lead to a decrease of inclusiveness, a partial delegitimisation and a general weakening of the decision-making process. If a stakeholder is only weakly connected with other stakeholders or even isolate, it does not mean that the perspective and viewpoint of this actor is unimportant. A second drawback of the method is that it does not extend the analysis with the qualitative evaluation of the network. This is not easy although the qualitative evaluation is typically of public interest. Questions such as private or public interests of individual stakeholders, the individual characteristics of the organisations and associations-NGO members and the local cultural context may be as interesting as the general pattern of the stakeholder relationships. Other potential limits of the method are typical for questionnaire surveys, such as incomplete answers or low reliability of the answers to certain questions.

About the practical utility for the TNP managers and planners, this approach to stakeholder analysis can be used to decide the different level of involvement of stakeholders in decision-making process, in order to balance the interests at stake. For example, Paletto et al. (2015) recommended to involve only the key stakeholders in a collaborative participation, where the number of stakeholders exceeds 30 . The other two categories of stakeholders may be involved for consultation (primary stakeholders) or are simply kept informed (secondary stakeholders). A less inclusive decision-making process may be faster, but it fails to consider all the stakeholders' point of view. A more inclusive process is without doubt slower, but, on the other hand, the needs and the necessities of the whole set of stakeholders are taken into con- sideration, so the power of the participatory approach is for sure enhanced. After the stakeholder analysis, the future steps of the recharge.green project in TNP will be to share with key stakeholders some scenarios aimed at the bioenergy development. Such scenarios will be presented and discussed during several public meetings or focus groups in order to reach a shared scenario. In this context, the definition of a standard technique to identify and classify the stakeholders that must be involved in the decision making is of fundamental importance in the participatory processes. If a stakeholder analysis is not objective and not able to identify all the interests at stake, it might affect the participatory decision-making process undermining the credibility (Cantiani 2012). Consequently, it is important to define and test techniques for stakeholder analysis objective and replicable in different contexts. The present research has tried to address this issue by proposing a method of stakeholder analysis based on experts' opinions. Surveying experts in forestry and environmental issues may reduce biases connected with the scarce knowledge of the technical aspects (Carnol et al. 2014). In this study, experts were fundamental because they had a broad knowledge of the actors involved in the decision-making process and of the territorial peculiarities.

\section{Conclusions}

Firstly, we want to highlight that to ensure a process as inclusive as possible, we used the stakeholder analysis before starting the participatory process in the RE development. The Alpine space is a very delicate area: extreme climate conditions, slow ecosystem dynamics with high pressures of human activities. Such an environment requires strategies of development capable to preserve the natural and social capital. The participatory process is proved to be very effective in guaranteeing a sustainable and long-lasting use of the natural resources (Walz et al. 2007). In particular, the sustainability of the bioenergy sector is very important for the protected areas (e.g. TNP), not only to accomplish the EU target on RE but also to fulfil the conservation aspects that have to be pursued in a protected area.

In conclusion, we point out that studies concerning relations between social network and RE development are influenced by a combination of factors and deeply 
rooted in the local socio-economic context. For this reason, case-study surveys offer ideas and insights that could be used to improve this field study. The proposed methodology based on the stakeholders and social network analysis is an important tool for including as much factors as possible in the land management strategies formulation.

\section{Acknowledgements}

This work was done in the framework of the EU recharge.green project (http://www.recharge-green.eu/ it/). The authors would like to thank the partners of the Triglav National Park (Tomaž Kralj and Renata Rozman) and the collaborators from the Biotechnical Faculty of the University of Ljubljana (Tina Simončič and Špela Ščap).

\section{References}

Bavelas A. 1950. Communication patterns in task oriented groups. Journal of the Acoustical Society of America, 22, 271-282.

Beurskens L.W.M., Hekkenberg M, Vethman P. 2011. Renewable energy projections as published in the national renewable energy action plans of the European Member states. ECN and EEA.

Blennow K., Persson E., Lindner M., Pacheco Faias S., Hanewinkel M. 2014. Forest owner motivations and attitudes towards supplying biomass for energy in Europe. Biomass and Bioenergy, 67, 223-230.

Bodin Ö., Crona B.I. 2009. The role of social networks in natural resource governance: What relational patterns make a difference? Global Environmental Change, 19, 366-374.

Borgatti S.P., Everett M.G., Freeman L.C. 2002. UCINET for Windows: Software for Social Network Analysis. Harvard: Analytic Technologies.

Bourgoin J. 2012. Sharpening the understanding of socio-ecological landscapes in participatory land-use planning. A case study in Lao PDR. Applied Geography, 34, 99-110.

Brass D.J. 1984. Being in the right place: a structural analysis of individual influence in an organization. Administrative Science Quarterly, 29, 518-539.
Cantiani M.G. 2012. Forest planning and public participation: a possible methodological approach. iForest, 5, 72-82.

Carnol M., Baeten L., Branquart E., Gregoire J.-C., Heughebaert A., Muys B., Ponette Q., Verheyen K. 2014. Ecosystem services of mixed species forest stands and monocultures: comparing practitioners' and scientists' perceptions with formal scientific knowledge. Forestry, 87 (5), 639-653.

Čiegis R., Gineitiene D. 2008. Participatory aspects of strategic sustainable development planning in local communities: experience of Lithuania. Ukio Technologinis ir Ekonominis Vystymas, 14 (2), 107-117.

Craig G. 2007. Community capacity-building: something old, something new? Critical Social Policy, 27, 335-359.

Driscoll C., Starik M. 2004. The primordial stakeholder: advancing the conceptual consideration of stakeholder status for the natural environment. Journal of Business Ethics, 49, 55-73.

Dwivedi P., Alavalapati J.R.R. 2009. Stakeholders' perceptions on forest biomass-based bioenergy development in the southern US. Energy Policy, 37, 1999-2007.

Evan W.M., Freeman R.E. 1988. A stakeholder theory of the modern corporation: Kantian capitalism. In: Ethical Theory and Business (eds.: T. Beauchamp, N. Bowie), Englewood Cliffs, Prentice Hall.

Everett M., Borgatti S.P. 2005. Ego network betweenness. Social networks, 27, 31-38.

Ernstson H., Sörlin S., Elmqvist T. 2008. Social movements and ecosystem services - the role of social network structure in protecting and managing urban green areas in Stockholm. Ecology and Society, 13 (2), 39.

Etzioni A. 1964. Modern organizations. Englewood Cliffs, Prentice Hall.

Freeman L.C. 1979. Centrality in social networks: I. Conceptual clarification. Social Networks, 1, 215-239.

Granovetter M. 1973. The strength of weak ties. American Journal of Sociology, 6, 1360-1380.

Gregory R., Wellman R. 2001. Bringing stakeholder values into environmental policy choices: a community-based estuary case study. Ecological Economics, 39 (1), 37-52. 
Grimble R., Chan M.K. 1995. Stakeholder analysis for natural resource management in developing countries. Natural Resources Forum, 19 (2), 113-124.

Grimble R., Wellard K. 1997. Stakeholder methodologies in natural resource management: a review of principles, contexts, experiences and opportunities. Agricultural Systems, 55 (2), 173-193.

Hahn T., Olsson P., Folke C., Johansson K. 2006. Trustbuilding, knowledge generation and organizational innovations: the role of a bridging organization for adaptive comanagement of a wetland landscape around Kristianstad, Sweden. Human Ecology, 34, 573-592.

Hamersley Chambers F., Beckley T. 2003. Public involvement in sustainable boreal forest management. In: Towards sustainable management of the boreal forest (ed.: P.J. Burton), National Research Council of Canada NRC Research Press, Ottawa, 113-154.

Higgs G., Berry R., Kidner D., Langford M. 2008. Using IT approaches to promote public participation in renewable energy planning: Prospects and challenges. Land Use Policy, 25 (4), 596-607.

Kangas A., Laukkanen S., J. Kangas J. 2006. Social choice theory and its applications in sustainable forest management - a review. Forest Policy and Economics, 9, 77-92.

Keltner D., Gruenfeld D.H., Anderson C. 2003. Power, approach, and inhibition. Psychological Review, 110, 265-284.

Korhonen K., Hujala T., Kurttila M. 2013. Diffusion of voluntary protection among family forest owners: decision process and success factors. Forest Policy and Economics, 26, 82-90.

Krackhardt D. 1990. Assessing the political landscape: structure, cognition, and power in organizations. Administrative Science Quarterly, 35, 342-369.

Kraxner F., Yang J., Yamagata Y. 2009. Attitudes towards forest, biomass and certification - a case study approach to integrate public opinion in Japan. Bioresource Technology, 100, 4058-4061.

Leavitt H.J. 1951. Some effects of certain communication patterns on group performance. Journal of $A b$ normal and Social Psychology, 46, 38-50.

Lisec A., Drobne S. 2009. The influence of protected natural and cultural heritage on land management/ market: the case of Slovenian natural protected areas. Spatium, 20, 41-48.
Lupo Stanghellini P.S. 2010. Stakeholder involvement in water management: the role of the stakeholder analysis within participatory processes. Water Policy, 12, 675-694.

Marsden P.V. 2002. Egocentric and sociocentric measures of network centrality. Social Networks, 24, 407-422.

Miron D., Preda M. 2009. Stakeholder Analysis of the Romanian Energy Sector. Review of International Comparative Management, 10 (5), 877-892.

Mitchell R., Agle B., Wood D. 1997. Towards a theory of stakeholder identification: defining the principle of who and what really counts. Academy of Management Review, 22 (4), 853-886.

Mizruchi M.S., Potts B.P. 1998. Centrality and power revisited: actor success in group decision making. Social Networks, 20, 353-387.

Newman M.E.J. 2005. A measure of betweenness centrality based on random walks. Social Networks, 27, 39-54.

Neal J.W. 2009. Network ties and mean lies: A relational approach to relational aggression. Journal of community psychology, 37 (6), 737-753.

Nichiforel R. 2011. Stakeholder analysis of the Romanian forest sector. The USV Annals of Economics and Public Administration, 11 (1), 114-125.

ODA. 1995. Guidance note on how to do stakeholder analysis of aid projects and programmes. Overseas Development Administration, London, UK.

Paletto A., Ferretti F., De Meo I. 2012. The Role of Social Networks in Forest Landscape Planning. Forest Policy and Economics, 15, 132-139.

Paletto A., Balest J., De Meo I., Giacovelli G., Grilli G. 2014a. Perceived influence and real power of stakeholders in forest management: a case study in Italy. In: Proceedings "Adaptation in forest management under changing framework conditions", $19^{\text {th }}-23^{\text {th }}$ May 2014 (eds.: E. Schiberna, M. Stark), Foundation for Sustainable Forest Management, Sopron, $163-175$.

Paletto A., Giacovelli G., Grilli G., Balest J., De Meo I. 2014b. Stakeholders' preferences and the assessment of forest ecosystem services: a comparative analysis in Italy. Journal of Forest Science, 60, 472-483.

Paletto A., Hamunen K., De Meo I. 2015. The social network analysis to support the stakeholder analy- 
sis in participatory forest planning. Society and Natural Resources, 28 (1), 1108-1125.

Pirlogea C., Cicea C. 2012. Econometric perspective of the energy consumption and economic growth relation in European Union. Renewable and Sustainable Energy Reviews, 16 (8), 5718-5726.

Prell C., Hubacek K., Reed M. 2009. Stakeholder analysis and social network analysis in natural resource management. Society and Natural Resources, 22, 501-518.

Pristov J., Pristov N., Zupančič B. 1998. Klima v Triglavskem narodnem parku. Razprave in raziskave 8 , Triglavski narodni park, Bled.

Proscovia Mutekanga F., Kessler A., Leber K., Visser S. 2013. The use of stakeholder analysis in integrated watershed management. Mountain Research and Development, 33 (2), 122-131.

Reed M.S., Graves A., Dandy N., Posthumus H., Hubacek K., Morris J., Prell C., Quinn C.H., Stringer L.C. 2009. Who's in and why? A typology of stakeholder analysis methods for natural resource management. Journal of Environmental Management, 90, 1933-1949.

Rinaldi F., Jonsson R., Sallnäs O., Trubins R. 2015. Behavioral modelling in a Decision Support System. Forests, 6, 311-327.

SFS. 2012. National forest inventory data. Ljubljana, Slovenian Forest Service.
Simpson J.A., Farrell A.K., Oriña M.M., Rothman A.J. 2014. Power and social influence in relationships. In: APA handbook of personality and social psychology (eds.: M. Mikulincer, P.R. Shaver), American Psychological Association, Washington, 393-420.

Stubelj Ars M. 2013. Evaluation of hikers' pro-environmental behavior in Triglav National Park, Slovenia. eco.mont - Journal on Protected Mountain Areas Research and Management, 5 (1), 35-42.

Svadlenak-Gomez K., Badura M., Kraxner F., Fuss S., Vettorato D., Walzer C. 2014. Valuing Alpine ecosystems: the recharge.green project will help decision-makers to reconcile renewable energy production and biodiversity conservation in the Alps. eco.mont - Journal on Protected Mountain Areas Research and Management, 5 (1), 59-62.

Turner J.C. 2005. Explaining the nature of power: A three-process theory. European Journal of Social Psychology, 35 (1), 1-22.

Walz A., Lardelli C., Behrendt H., Grêt-Regamey A., Lundström C., Kytzia S., Bebi P. 2007. Participatory scenario analysis for integrated regional modelling. Landscape and Urban Planning, 81 (1/2), 114-131.

Wasserman S., Faust K. 1994. Social network analysis. Cambridge University Press, Cambridge. 